\title{
Opetuksen laatukin vaikuttaa työhön pääsyyn
}

$\mathrm{K}_{\mathrm{i}}$ orkea työttömyysaste on yhteiskuntien suuvitsaus ja uhka hyvinvoinnille. Parhaiten menee Yhdysvalloissa, jossa yleinen työttömyysprosentti on alle neljän, kun taas Suomessa kamppaillaan kymmenen prosentin tietämissä. Erityisen rankkaa on nuorilla, joista moni joutuu koulutuksen päätyttyä odottelemaan ensimmäistä työpaikkaansa pitkään. Kaksikymmentä vuotta sitten pidetyssä OECD-maiden nuorisotyöttömyyttä käsitelleessä konferenssissa uskottiin, että taloudellinen kasvu itsessään minimoi ongelman (Preparing youth for the 21 st century, 1999). Todellisuus on ollut toista. Tarvitaan siis tutkimusta keinoista, joilla nuoria voitaisiin auttaa nykyistä jouhevampaan työelämään siirtymiseen. OECD teki siitä analyysin "From initial education to working life" (2000), jonka tuoman kehikon puitteissa tutkimusta jatketaan keskittymällä erityisesti tiedotus- ja ohjausjärjestelmiin.

Työttömyys on sekä rakenteellista että suhdanteista johtuvaa. Sekä Yhdysvalloissa että IsossaBritanniassa nuorten työttömyys selittyy erityisesti rakenteellisilla sosiaalis-taloudellisilla taustatekijöillä. Yhdysvalloista kolmannes mustaan västönosaan kuuluvista nuorista miehistä ja neljännes saman väestönosan naisista on työttöminä. Toisten laskelmien mukaan Yhdysvalloissa vähemmistöihin kuuluvien nuorten työttömyysaste on 50 prosenttia. Myös muualla voidaan havaita rakenteellisia tekijöitä (esimerkiksi Saksassa), mutta suhdannetekijät ovat vallitsevia. Kaikissa maissa suhdannevaihtelut eivät kuitenkaan ole heitelleet nuoria sen pahemmin kuin muutakaan väestöä. Esimerkkeinä siitä ovat Saksa, Irlanti ja Alankomaat.

Y htenä keskeisenä työmarkkinoille pääsyn epäonnistumisen syynä pidetään heikkoa koulutustasoa. Ongelmana on myös, että monilta nuorilta puuttuu työn hakemisen ja tekemisen kulttuurinen tausta. EU-maiden nuorista työttömistä vuonna 1985 viidennes tuli kotitalouksista, joiden jäsenistä yhdelläkään ei ollut työtä. Tuo osuus nousi neljännekseen vuonna 1996 ja on nyt jo 36 prosenttia.

Koulutuksesta työelämään siirtymisen vaikeudet eivät johdu yksittäisestä syystä, vaan siirtymiseen liittyvien tapahtumien sarjasta, jossa erityisesti varhaiset epäonnistumisen kokemukset saattavat olla lannistavia. Nuorten työelämäkokemukset poikkeavat usein aikuisten kokemuksista. $\mathrm{He}$ vaihtavat työtä aikuisia enemmän ja kokevat usein peräkkäin työllistymisen ja työttömyyden jaksoja. Tällaiset muutokset voivat olla joillekin ihmisille vaikeita siitä huolimatta, että ne olisivat ainoa mahdollisuus saada otetta työelämästä.

Kysymykseen siitä, voidaanko nuorten auttamista tehostaa, on saatu pessimistisiä ja optimistisia vastauksia. Yhdysvalloissa työmarkkinaohjelmien heikot evaluaatiotulokset ovat johtaneet jopa näkemyksiin, että hallituksen tulisi huolehtia työmarkkinoiden toimivuudesta ja opetustoimesta, mutta jättää loppu nuorten ja työnantajien varaan. Silti siellä, Euroopassa ja Japanissakin on voitu esittää myös myönteisiä kokemuksia. Erityisen onnistuneiksi mainitaan saksalainen oppisopimuskoulutus ja japanilainen kontaktijärjestelmä, jossa yritykset rekrytoivat jo toisen asteen koulutusvaiheen jälkeen oppilaita suoraan koulun penkiltä pysyviin työsuhteisiin. Koulutuksen ja työelämän välisten suhteiden järjestämisellä voidaan siis edesauttaa työelämään integroitumista.

T yöelämään siirrytään yhä iäkkäämpinä. Toisen asteen koulutuksen arvo on tiedostettu, joten yhä useampi yltää sen suorittamiseen. Näin myös koulutuksen keskeyttäminen on vähentynyt. Teknisenä selityksenä on, että monissa maissa toisen asteen koulutusohjelmien pituutta on lisätty ja osa oppilaista suorittaa useamman kuin yhden tutkinnon. Myös työpaikkojen puute on viivyttämässä siirtymistä. 
$\mathrm{M}^{\mathrm{s}}$ yös nuorten arvoissa arvellaan tapahtuneen muutoksia. Tämän päivän nuoret ovat kuin vuoden 1968 opiskelijat, jotka haluavat muuttaa maailmaa. Kapina kuuluu nuoruuteen, mutta nyt sen välineet ovat uusia perustuen $\mathrm{mm}$. teknologian käyttöön. Välivuosina halutaan nähdä maailmaa. Tärkeänä pidetään päästä tekemään arvostettua työtä, jolloin kaikki ei siis kelpaa. Tässä elämänvaiheessa nuoret kohtaavat usein muitakin suuria muutoksia: aikuisen roolin omaksumisen, taloudellinen itsenäistymisen, irtautumisen kotoa ja oman perheen perustamisen. Työelämään siirtymistä auttavat tekijät voidaan erotella taloudelliseen, sosiaaliseen ja kulttuuriseen toimintaympäristöön ja henkilökohtaisiin ominaisuuksiin.

$\mathrm{K}^{2}$ oulutusväylien suosiossa on voitu nähdä selvä nuutos. Oppilasmäärät vähenivät 1990-luvulla yleisesti sellaisessa ammatillisessa koulutuksessa, josta ei ole siltaa kolmannen asteen koulutukseen. Vastaavasti jatkokoulutusmahdollisuudet turvaavien koulutusväylien vetovoima on lisääntynyt. Toisen asteen koulutukseen kytketään yhä useammin työelämässä tapahtuvia koulutuksen jaksoja tai muita työelämäyhteyksiä. Myös opiskelijoiden osa-aikatyö on yleistynyt, mikä helpottaa työkulttuurin omaksumista.

Myöhentynyt siirtyminen työelämään sisältää sekä myönteisiä että kielteisiä piirteitä. Se kertoo koulutuksen keskenjättämisen vähenemisestä, mikä nostaa väestön koulutustasoa. Ongelma muodostuu siitä, jos koulutusväylien joustamattomuus, kapeus ja umpiperät johtavat useammankertaiseen toisen asteen tutkinnon suorittamiseen.

Keskeisin työelämään siirtymistä nopeuttava tekijä on hyvä yleinen taloudellinen tilanne. Silloinkin työmarkkinoiden tulisi omaksua "nuorisoystävällisiä" toimintaperiaatteita. Eri koulutusväylien (ammatillinen, yleissivistävä, oppisopimus) työelämävastaavuutta pitää lisätä mm. vahvistamalla ohjelmien joustavuutta ja kytkemällä ne jatko-opintoihin. Koulutuksessa pitää järjestää mahdollisuuksia saada kokemuksia työelämästä. Riskiryhmiä varten pitää luoda turvaverkot. Työelämää koskevan tiedotuksen ja ammatinvalinnanohjauksen pitää olla tehokasta. \oulutuksen ainainen vaikeus on sen tietämisessä, millaiseen maailmaan pitäisi kouluttaa. Nyt peruskoulun ensimmäisellä luokalla olevat tulevat työelämään pääosin vuosina 2012 2016 siitä riippuen, mille koulutusasteelle kukin heistä yltää. Tulevaisuutta tehdään heidän kanssaan jo tänään. Keskeisen tärkeätä on huolehtia, että varhaiset oppimiskokemukset muodostuvat myönteisiksi, sillä epäonnistumisen kulttuuri ruokkii itse itseään. Halu oppia lisää ja uutta pitäisi voida sisäistää ja säilyttää. Toinen yhtä tärkeä seikka on se, mitä opetetaan. Elinikäistä oppimista käsittelevissä visioissa korostuvat tarve perusopetuksen laaja-alaisuuteen, informaatio- ja kommunikaatioteknologian käytön opettaminen kaikille ja kansainvälistymisestä johtuva kielten osaamisen merkitys.

$\mathrm{M}$ utta miten oppi menee perille, jos opetusmenetelmissä ei kehitytä? Kirjassaan Toute vérité est bonne à dire (2000) Lionel Jospinin hallituksen edellinen opetus- ja tiedeministeri Claude Allègre arvostelee ranskalaista koululaitosta yhteiskunnasta vieraantumisesta. Kouluilla ei ole yhteyksiä yritysmaailmaan. Niissä opetetaan teoriaa, mutta ei käytäntöä. Opettajien käyttämä kieli ei avaudu oppilaille. Allègre on siviilissä fysiikan professori, joten hän tietänee, mistä puhuu, sillä hänen antamansa esimerkit ovat juuri fysiikan opetuksesta. Miksiköhän Suomessakaan juuri fysiikan alalle ei tahdota saada opiskelijoita? Olisikin erityisen tärkeätä poistaa koulujen välisiä eroja opetuksen laadussa, sillä myös koulun valitsemisen arpapeli on ratkaisemassa koulutuksessa saadun pääoman vaihtoarvoa.

Reijo Laukkanen 